\title{
EQUITY CROWDFUNDING AS A TYPE OF PROJECT INVESTING
}

\author{
D. Blagoev*, K. Petkov
}

\author{
Industrial Business Department, University of National and World Economy, Sofia, Bulgaria
}

\begin{abstract}
PURPOSE. The Article aims to present the potential and capabilities of the application of equity crowdfunding as an option to invest and to form investment portfolios for the individual investors. The emphasis is shifted from the widespread use of the concept of crowdfunding, as a cutting-edge source for providing capital for investment projects of innovative companies (especially suitable source for the so called Startup companies), to its use as a tool for establishing an investment portfolio based on appropriate balance between the rates of return and risk.

METHODS. Various authors' views on key concepts such as investments, projects, investment projects, equity collective investment, investment portfolios, etc. have been clarified and summarized. The investment process is explained in the context of creating a portfolio of investments using equity crowdfunding platforms. Conceptually, the essential characteristic of the project theory, the theory of collective investment, with its methodological and mathematical tools, are revealed.

RESULTS. On this theoretical basis and adaptation, a conceptual methodological model has been developed, to be used for selection of portfolio of investment projects for equity collective investment. The model focuses on the optimization of rate of return, given the risk nature of the financial investment instrument used in collective investment.

CONCLUSIONS. Conclusions are presented about the main advantages and the respective limitations of the type of investments, subject of the paper.
\end{abstract}

Keywords: Investment, Project, Equity Crowdfunding, Portfolio Management, Entrepreneurship, Start-Ups

JEL Classification: G11, G32, C61, L0

\section{INTRODUCTION}

Investment analysis and portfolio management helps the management of business organizations (companies) to deepen the essential characteristics of the various investment projects they implement and are used as an appropriate methodological tool for making robust investment decisions. This is of course not an easy process, and besides having a good knowledge of the types of investment assets and investment theories, it is necessary to have a good knowledge of the theories of portfolio investment management. The main theoretical investment concepts and portfolio management theory are based on financial investments and allow to analyze the

\footnotetext{
*Correspondence to: Dimitar Blagoev, Industrial Business Department, University of National and World Economy, "Osmi dekemvri" str., 1700

Studentski grad, Sofia, Bulgaria, telephone: +3592 8195 512,blagoev@unwe.bg
}

investment process and investment management decisions in a considerably wider context. Based on the presumption that a large part of the investments of start-up innovative business organizations (Start-ups) are real and not financial assets, and the fact that the investor needs to know on the one hand the specificity of investing in real assets (the investment will be made by the innovative company to which it provides financial resources) and the specificity of investing in financial assets (i.e. collective equity funding is a type of financial investment), we offer a combination of the classical portfolio theory of Harry Markowitz for the purposes of portfolio management of investments in investment and the formation of investment packages based on crowd equity funding. To accomplish this goal, the theoretical aspects of investment, projects, investment projects and portfolio management, equity crowd funding and its application in raising capital for undertaking high-risk 
innovative projects by companies are explored. Emphasis is placed on developing a conceptual framework for distributing the financial resources of the investor in many investment projects of innovative companies based on the principles and principles of shared equity financing and the built platforms mediating this process at Startup companies.

\section{Investment projects and investing in projects}

Projects play an important role in the economic development of a company (business organization). Since its inception, business organizations have invested a great deal of resources (money, time, labor) in all phases of their life cycle (growth, development, maturity, restructuring) in a number of projects related to their real assets, resources and materials, ), transport and logistics, product realization, education, etc., in order to improve socioeconomic conditions in the company and create conditions and prerequisites for growth and development, development of new products and / or services (most often with a high degree of innovation). These projects are designed to efficiently manage, gain adequate returns to ensure future development with own (and / or attracted) resources (funds).

Many people and organizations define what is meant or is to be understood by the term "project", but perhaps the most authoritative definition is given in BS 6079 "Project Management Guide", which defines the project as "A unique set of coordinated activities with defined start and exit points taken by a person or organization to achieve specific objectives within a defined schedule, cost and operational parameters " (1). The above definition shows that the term project has a broader meaning but is necessarily accomplished by performing a set of activities. Another aspect of the project is the non-routine nature of the activities. Each project is unique in the sense that the activities of a project are unique and non-routine. The implementation of a project necessarily implies the use of a set of resources. The resources needed to complete the project are people, materials, money and time. In this way, we can define the project as an organized program from a predetermined group of activities that are not routine in nature and which need to be completed using the available resources within the set deadline (2).

Newman et. al. defines that the project definitely has a separate mission, which must also achieve a clearly defined end point for achieving its mission (3).

Gillinger defines a "project" as the entire set of activities related to the use of resources to obtain results (benefits) (4). Project Management Institute, USA, defines the project as "a system involving the coordination of a number of separate units and departments throughout the organization in a way aimed at completing a job in the prescribed schedules and time constraints and resources" (5).

According to the Encyclopedia of Management, "The project is an organized unit dedicated to the achievement of a certain objective, brought to a successful and timely conclusion within the budget, according to a predefined program specification" (6).

The characteristics of a project can be reduced to the following: (1) Objectives: The project has a set of objectives or a mission. Once the objectives have been achieved, the project is treated as completed; (2) Lifecycle: The project has a life cycle. The life cycle of a project consists of five stages, ie: stage of design, definition stage, planning and organization stage, stage of implementation and commissioning phase; (3) Uniqueness in features: each project is unique and no pair of projects are the same in their characteristics; (4) Teamwork: The project involves teamwork and usually team members are professionals from different functional areas. Coordination between these different areas requires teamwork and successful cooperation; (5) Complexity: the project is a complex set of activities related to different areas; (6) Risk and uncertainty: risk and uncertainty go hand in hand with the project. It can be visible or invisible, predictable or not, but always present in a project; (7) Clientspecific character: The project is always customer-specific; (8) Change: there are changes in the life cycle of the project as a natural result of many environmental factors. Changes may range from minor, minor impacts to the project to significant changes that can have a major impact or even change the very nature of the project; (9) Optimality: The project is always aimed at optimal use of resources for the overall development of the company; (10) Subcontractors: the large volume of work in a project implies the need to use subcontractors. The greater the complexity of a project, the more will be the degree of socalled. outsourcing; (11) Unity in Diversity: 
the project is a complex set of thousands of elements that relate to technologies, equipment and materials, machinery and people, work, culture, and so on. Their unity and skillful (successful) combination are a prerequisite for the successful realization of the project (7).

From all the definitions considered, it can be traced that the specific characteristics of a project are defined as: activities (defined, ordered and coordinated), start and end (time constraints), timetable, resources (time, human, financial), result (financial or not). By reframing these features of the concept of project from the point of view of investments we can also define the concept of investment and investment project.

An essential element of each project and a prerequisite for its successful realization is the need to invest in a specific resource that is expected to produce a positive result or, in other words, it is necessary to make specific investments. Investments are defined as the engagement of funds made in anticipation of obtaining an appropriate rate of return. If the investment action is properly undertaken, the return will correspond to the risk the investor assumes (8).

A basic (basic) definition of a capital investment is that it is an investment in a real asset that is expected to lead to future returns (9). For a company, this may for example be an investment aimed at increasing capacity, improving product quality, or contributing to resource efficiency.

In his book Fundamentals of Investing, Ivan Georgiev provides a comprehensive definition of investments, which expresses their essential characteristics and their way of expression in business organizations. He defines investments as "cash to buy (or build) assets that are sufficiently likely to provide income, capital growth and other positive results over a long period." (10).

The importance of capital investment is further underlined by Lumijärvi (11), who states that "investments affect operations and cash flows of firms over a long period of time, making investment success extremely important." Capital investment decisions are also cited as an important means of implementing strategies (12) and guaranteeing the company's performance (13). Making investment decisions is a matter of making decisions on resource allocation (most often but not just financially) (14), and studies show that firms that have so-called "more financial maneuvering opportunities," ie more available resources, have a less formalized investment decision-making process (15). However, as businesses usually have limited resources available, decision-making on allocation across different investment decisions is crucial (11). The question then is how do companies, on the one hand, and the investors who provide them with financial resources on the other hand, take these important investment decisions?

Of course, the specificity of the investments combined with the characteristics of the projects and their overall process organization suggest that to some extent there are both general and specific features of the investment projects (both investment in real assets and investment in financial assets), in comparison with other types of projects in a business organization. In other words, each investment project is a project, but not every project is an investment project. In this respect, the question is how to define the investment project?

According to Ivan Georgiev (10), investment projects are a one-time investment of cash in some assets (tangible, intangible and/or financial) to secure income and / or other positive results over a prolonged period. $\mathrm{He}$ also states that projects differ in too many ways: scale (large, small); assets (real, financial); areas (markets, production, etc.); objectives (cost minimization, revenue increase, capacity increase); risk (high-risk, low-risk); way of development (with its own forces, by external units) and variance (complementary, mutually exclusive), etc.

In her dissertation study Vania Pandakova states that an "investment project" should be understood as a unique set of interrelated activities aimed at achieving a clearly defined goal related to the construction of new or renovation of existing buildings and facilities through new construction, reconstruction, modernization and major overhaul, of which the main feature is the execution of construction and assembly works, within a defined time period, at a set value and quality requirements $\mathrm{o}$, and at predetermined permissible levels of risk (16).

Investment projects are a long-term allocation of funds (with or without recourse to external project financing) to realize an 
BLAGOEV D., et al.

investment idea until the stable income generation phase. A viable investment project aims to achieve a profitable return that ensures (1) timely payment of interest and principal on its external sources of financing, satisfactory return on invested capital, and (3) positive and consistent cash flows.

There are many investment opportunities in business practice, each of which is linked to a variety of return and risk compromises. Each investment project is different in terms of its characteristics, making the investment decision a challenging process. In this way, the investor must carefully analyze each of the characteristics and build a portfolio of investment projects to invest in real assets that correspond to its risk profile and is in line with the company's goals and objectives, strategy, etc. (17)

Making an investment decision is an ongoing process, first developed by Cyert and March (18). However, surveys on how to make capital investment decisions typically focus on the financial assessment of investments, such as the use of capital budgeting tools and practices (19-23).

Although financial assessment plays an important role in investment decisions (15), this is just one step in the process (24) and "corporate investment behavior is considerably more complex than can be described by the core concept of NPV as a model of investment" (25).

All of this gives us reason to proceed with the development of a methodology adapted on the basis of different investment concepts and concepts for portfolio management of investment projects, on the basis of which to seek and achieve optimization and a wellchosen selection of individual projects included in one investment portfolio of the business organization, by key features. The basis is the concept of managing the portfolio of Harry Markowitz (26) which is adapted and interpreted for the needs of portfolio management of investment projects when investing in real assets by business organizations.

\section{Collective Funding (Crowdfunding) as an investment tool.}

Crowdfunding has emerged as novel way for entrepreneurial ventures to secure funds without having to seek out venture capital or other traditional sources of venture investment (27). Another description sees crowdfunding as a tool that allows founders of for-profit, artistic, and cultural ventures to fund their efforts by drawing on relatively small contributions from a relatively large number of individuals using the internet, without standard financial intermediaries (27). For the purposes of this paper, we shall perceive the crowdfunding models, as presented in the EU Commission's staff working document "Crowdfunding in the EU Capital Markets Union" (28). They define it as a process, that "refers to an open call to the public to raise funds for a specific project". Crowdfunding platforms are websites that enable interaction between fundraisers and the crowd. Financial pledges can be made and collected through the platform.

The different business models that are used by crowdfunding platforms can be grouped under the following broad categories (29):

Investment-based
crowdfunding (Equity crowdfunding): Companies issue equity or debt instruments to crowd- investors through a platform. The current research is dedicated to this model.

\section{Lending-based}

crowdfunding (also known as crowdlending, peer-to-peer or marketplace lending): Companies or individuals seek to obtain funds from the public through platforms in the form of a loan agreement.

- Invoice

trading

crowdfunding: a form of asset-based financing whereby businesses sell unpaid invoices or receivables, individually or in a bundle, to a pool of investors through an online platform.

\section{Reward-based}

crowdfunding: Individuals donate to a project or business with expectations of receiving in return a non-financial reward, such as goods or services, at a later stage in exchange of their contribution.

\section{- Donation-based}

crowdfunding: Individuals donate amounts to meet the larger funding aim of a specific charitable project while receiving no financial or material return.

$$
\text { - Hybrid models of }
$$

crowdfunding: those that combine elements of the other types of crowdfunding.

Equity crowdfunding, as a new phenomenon in the early stage investing is by far one of the most intriguing options, available to both 
entrepreneurs and investors. General benefits of the product or service are an important factor for crowd investors, as these are usually the first aspects to appeal to funders and create initial interest in an investment (30). It is about connecting young companies that deserve a chance to get funded with retail investors who want a chance to get in on early-stage investments. What equity crowdfunding basically does, is allowing start-ups to use internet to raise capital. The essence of the equity crowdfunding model is about networking innovative, young companies that need capital to fund initial investments, with the general crowd of investors who are looking for the opportunity to get in on early-stage investments.

While equity investors ("crowdfunders" or "backers") do focus on numbers, they often consider numbers to be less important than traditional investors, mostly due to a lack of access to business information and to less expertise in reading and interpreting financial and business documents (31). Perception of the founder or founding team who is issuing the campaign, is deemed equally important in crowdfunding and an offline setting, but the lack of physical access to the campaign initiators requires investors to rely on substitutes to judge them (32). Such substitutes could be the product videos, responsiveness to questions, or previous successful campaigns on the same platform (33). The crowd of potential investors usually does not possess the necessary expertise and insights needed when making investment decisions. Generally, SME investors tend to possess inadequate knowledge of the opportunities that the capital market provides (34). Crowd investors often rely on other measures, and decisions are influenced much more by the behavior of other investors and the context of a decision (35) both factors that are less well researched in the traditional investment literature. Amateurs seem to approach equity crowdfunding in a less structured way and therefore often don't have a sustainable diversified portfolio at heart (36).

To ensure that investment portfolios are in the best possible position to achieve the profitability goals of the investors, a series of optimization approaches should be considered.

Optimization solutions for investing through Crowdfunding (based on the example of the Portfolio Theory and the Project Management Theory)
In building a portfolio of innovative projects where an investor invests his money by buying shares from collective financing platforms, one of the key points is the selection of the most appropriate innovation projects from the wide variety of existing ones on these platforms. In theory and practice, there are a number of proposed procedures for deciding which innovative projects (or which shares of innovative companies) are preferred. It is important to note that in order for the selection to be successful, it must meet two important conditions. First, before the implementation of the process necessary clarification of indicators (criteria), which will be selected shares (innovative projects). They should be clearly defined and the same for all options. Second, no matter what method will be chosen for the selection itself, it is necessary to allow the use of the selected indicators (criteria) on which the shares will be selected (the innovative projects).

\section{Mean-variance optimization}

The Mean-variance method for selecting a stock package was developed by Markowitz (26). A number of other authors work with this theory and on its perfection (37-41). This method uses non-linear programming, and the input parameters for the analysis are: expected return, dispersion, covariance and desired yield or level of desired risk. The method has two varieties: a minimum risk at a certain yield and a maximum yield at a certain risk. The first option looks for the best combination of shares that has the lowest risk, measured by the portfolio's dispersion, at the investor's return. In the case of the maximum yield at a certain risk, the opposite case is observed. It determines the level of risk that is assumed and constructs the portfolio with maximum yield at the appropriate level of risk.

\section{Linear optimization models}

Linear optimization methods are a further development of the methods proposed by Markowitz (42). In order to apply linear optimization, a different risk indicator from the standard - dispersion should be used. The method of Konno and Yamazaki (43) uses an average linear deviation for the risk measure.

The main advantage of this method is the use of an average linear deviation instead of a dispersion, which reduces the model to a linear optimization model and does not require the calculation of covariance between the shares. Another significant advantage is the possibility 
to use historical data as well as forecasts of the return on shares and even a combination of both. For innovative companies, this is a little more difficult, because they have no serious history and data on their financial performance is scarce.

Table 1. Advantages and disadvantages of "mean-variance" optimization

\begin{tabular}{|l|l|}
\hline Advantages & Disadvantages \\
\hline $\begin{array}{l}\text { Flexibility and adaptability to the needs of the } \\
\text { investor. }\end{array}$ & $\begin{array}{l}\text { In the case of incorrect input, the characteristics of the } \\
\text { portfolio received will be different from those } \\
\text { required by the investor. }\end{array}$ \\
$\begin{array}{l}\text { The resulting portfolio is the most accurate version of } \\
\text { the available data. }\end{array}$ & \\
\hline
\end{tabular}

Source: Patev, Plamen, and Nigogos Canaryan. Portfolio Management, Abagar Publishing House, Veliko Tarnovo, 2008

\section{Selection by Ranking}

The criticism of optimization methods for stock selection justifies the search for other methods (44) that have no disadvantages such as:

- Workload and need for serious knowledge about generating the correlation matrix;

- Investors' difficulties in understanding the meaning of concepts such as covariance, dispersion and standard deviation;
- Scarcity of financial information for start-up innovative companies (very often they are newly registered or with a history of only 2-3 years, which makes it difficult to form a database to realize the necessary calculations in applying the optimization models considered.

Table 2. Methods of selecting a project

\begin{tabular}{|c|c|}
\hline Method & Description \\
\hline $\begin{array}{l}\text { Analytical hierarchical } \\
\text { process (AHP), (46) }\end{array}$ & $\begin{array}{l}\text { The choice of the best alternative is based on a qualitative and quantitative approach } \\
\text { (subjective and pairs comparisons). }\end{array}$ \\
\hline Balloon Diagrams (47) & $\begin{array}{l}\text { In this type of diagram, one dimension is interest in qualitative and quantitative } \\
\text { analysis of project revenue and benefits, while the other is related to uncertainty and } \\
\text { risk. Within both dimensions, there are four quadrants for project allocation. }\end{array}$ \\
\hline $\begin{array}{l}\text { Hierarchical Selection } \\
\text { Process in Portfolio (48) }\end{array}$ & $\begin{array}{l}\text { The portfolio selection portfolio in the portfolio consists of two levels. The first level } \\
\text { is related to strategic portfolio decisions. The second level is called a tactical portfolio } \\
\text { solution and is actually the very process of selecting projects. }\end{array}$ \\
\hline $\begin{array}{l}\text { Matrix of the Boston } \\
\text { Consultant Group } \\
(49)\end{array}$ & $\begin{array}{l}\text { In the BCG matrix, a portfolio of products is managed on two dimensions: market } \\
\text { share and market growth; and four segments: stars; dairy cows; dogs; question marks. } \\
\text { The four segments represent the life cycle of the product. }\end{array}$ \\
\hline $\begin{array}{l}\text { Mental decision-making } \\
\text { process for portfolio } \\
\text { selection }(50)\end{array}$ & $\begin{array}{l}\text { The four steps that are at the heart of the process are as follows: 1) What the } \\
\text { organization should do; 2) What the organization can do; 3) Analysis and project } \\
\text { selection; 4) Implementation of the plan. }\end{array}$ \\
\hline $\begin{array}{l}\text { Model of Archer and } \\
\text { Ghasemzadeh (51) }\end{array}$ & $\begin{array}{l}\text { The model consists of three phases of selection: 1) taking into account the strategic } \\
\text { guidelines for forming the project portfolio; 2) individual project appraisal; 3) } \\
\text { selection of appropriate projects in the portfolio. }\end{array}$ \\
\hline $\begin{array}{l}\text { Expected Sales Value } \\
(\text { ECV }),(52)\end{array}$ & $\begin{array}{l}\text { Also known as the method - the tree of solutions. Used to maximize the expected } \\
\text { value of the portfolio. The method takes precedence over the weakness of the net } \\
\text { present value as it manages to address the risk, probability of technical and } \\
\text { commercial success. }\end{array}$ \\
\hline $\begin{array}{l}\text { Financial Evaluation } \\
\text { Profile (FAP) (53) }\end{array}$ & $\begin{array}{l}\text { The model consists of three sub models: Net Present Value (NPVP) profile, Project } \\
\text { Risk Profile (PRP), and Strategic Index (SI). According to the author, this model is } \\
\text { able to evaluate three main attributes of the projects: financing, risk and strategic } \\
\text { benefits. }\end{array}$ \\
\hline $\begin{array}{l}\text { Comparative methods } \\
(54)\end{array}$ & $\begin{array}{l}\text { The essence of these methods is based on the comparison of individual projects. A } \\
\text { choice is made for a certain prioritization based on selected criteria. An example is a } \\
\text { "polar chart" that can be used to compare two project proposals }\end{array}$ \\
\hline $\begin{array}{l}\text { Benefit-Cost Ratio and } \\
\text { Profitability Index (55) }\end{array}$ & $\begin{array}{l}\text { A weighted benefit vs. cost analysis is better known as cost-benefit analysis (B / C). } \\
\text { The ratio is calculated by dividing the estimates of the benefits of the cost estimates. } \\
\text { It is mainly used for public projects. }\end{array}$ \\
\hline
\end{tabular}

Source: Angelova, Ant. Criteria and Methods of Selection of a Project in a Project Portfolio in Contemporary Business Conditions ". Scientific Works of UNWE - Volume 2/2017. 
Ranking as a method of selecting investment stocks offers an alternative to optimization methods. The logic of this method is to rank the assets in descending order by a selected indicator and to include those that meet the selected ranking criteria.

Such a method is the Elton and Gruber (45) method of stock selection. In this case, the market risk was selected as the main indicator.

The input data required to implement the method are: expected return on assets, risk-free rate of return, beta asset ratio, market risk and nonsystematic asset risk. The main advantage of the method is the lack of complex mathematical procedures when compiling the optimal portfolio.

It is worth noting that apart from the purely mechanical purchase of shares, through the platforms for group financing of innovative projects, behind each company (which owns shares) is also a specific project idea for the respective innovation. In this direction, it is also important to look at the specific methods of selecting no longer separate financial assets (such as shares) and the relevant innovation projects (from a wide variety of similar in group finance platforms).

Methods for selecting projects in project portfolio (from the perspective of project management theory)

Methods of selecting projects in a project portfolio have been developed not specifically for investment projects, but for the needs of the management of project-oriented business organizations. The principles set out in these methods need to be taken into account and used in forming and selecting a portfolio of shares when investing in innovative companies seeking financing their innovative projects through collective finance sites.

Unlike the methods of selecting shares in project selection methods, leading indicators of choice are not the risk and return, but the company strategy and the relationship between project objectives and business objectives. Here the financial indicators are not leading. This is due to the different purposes for which the two types of portfolios are used. However, it should be noted that the methods of selecting a project portfolio do not exclude financial indicators. They are included in a different way in the presented methods.

\section{CONCLUSION}

When creating a portfolio of shares of companies looking to finance their innovative
BLAGOEV D., et al.

projects, it is not possible to choose only the methods of stock selection or project portfolio. In most cases, they are considered to lead to the return and risk of the project, but innovative projects are complex. In many cases, the idea of innovation pursues less shortterm or medium-term goals, but longer-term consumption patterns and the fulfillment of unconscious needs.

The analysis should support the endeavor to build better theories and provide a basis for further developing the portfolio management models for equity crowdfunding. Further, a more comprehensive understanding of how investment decisions in crowdfunding settings are made, will provide models and tools to be used by such investors, optimizing their portfolios. Also, this could provide new perspectives on regulating investments on such platforms, thus protecting investors from rash and potentially costly choices. These are research questions, which could be investigated further in future reviews.

\section{REFERENCES}

1. Cater, T. 'A Guide to Project Management (An introduction to principals and practice), Second edition', Business Performance Pty Ltd., Victoria, Australia, p. 55, 2008.

2. Chandra, P. 'Projects: planning, analysis, selection, implementation, and review', New Delhi; Sydney: Tata McGraw-Hill, 1995.

3. Choudhury, S. (Sadhan) Project management. 32nd reprint. New Delhi India: Tata McGraw-Hill, 1988.

4. Shaghil, M. and Mushtaque, M. Project Planning and Management Vol. 1, 1997.

5. Project Management Institute, A Guide to the Project Management Body of Knowledge (PMBOK® Guide), 2017.

6. Kessler, E. H. Encyclopedia of management theory. SAGE, 2013.

7. Wallace, W. 'Project Management'. Edinburgh Business School, Heriot-Watt University, Edinburgh, United Kingdom, p. 16, 2014.

8. Fischer, D. E., R.J. Jordan., Security Analysis and Portfolio Management (Sixth Edition). Prentice Hall International Inc., 1975.

9. Brealey, R. A., Myers, S. C., Allen, F. Principles of Corporate Finance. 10th ed. McGraw-Hill, 2011. 
10.Georgiev, Iv. Fundamentals of Investing. University of National and World Economy, Sofia, 2017.

11.Lumijärvi, O. P. Selling of capital investments to top management. Management Accounting Research 2: pp 171-188, 1991.

12.Grundy, T. and Johnson, G. Managers' Perspectives on Making Major Investment Decisions: the Problem of Linking Strategic and Financial Appraisal. British Journal of Management 4: pp 253-267, 1993.

13.Emmanuel, C., Harris, E., Komakech, S. Towards a better understanding of capital investment decisions. Journal of Accounting and Organizational Change 6(4): pp 477-504, 2010.

14.Bower, J. L. Managing the Resource Allocation Process. Harvard Business School Press Books, 1986.

15.Van Cauwenbergh, A., Durinck, E., Martens, R., Laveren, E., Bogaert, I. On the role and function of formal analysis in strategic investment decision processes: results from an empirical study in Belgium. Management Accounting Research 7: pp 169-184, 1996.

16.Pandakova, Vanya (2015), Improving the management of investment projects in the construction of shopping malls, Dissertation work for the acquisition of Doctor's School, Faculty of Economics, Faculty of Economics, Varna (autoreprefect), p.

17.Introduction to Investments, A study on investment pattern amongst academicians in Bangalore, online on: http://shodhganga.inflibnet.ac.in/bitstream/ 10603/92732/7/10.chapter\%201\%20(introd uction\%20to\%20investments).pdf

18.Cyert, R. M. and March, J. G. A behavioral theory of the firm. Prentice-Hall Inc, Englewood Cliffs New Jersey, 1963.

19.Bennouna, K., Meredith, G. G., Marchant, T. Improved capital budgeting decision making: evidence from Canada. Management Decision 48(2): pp 225-247, 2010.

20.Graham, J. R. and Harvey, C. R. The theory and practice of corporate finance: evidence from the field. Journal of Financial Economics 60: pp 87-243, 2001.

21.Lefley, F. The payback method for investment appraisal: A review and synthesis. International Journal of Production Economics 44: pp 207-224, 1996.
BLAGOEV D., et al.

22.Sandahl, G. and Sjögren, S. Capital budgeting methods among Sweden's largest groups of companies. The state of the art and a comparison with earlier studies. International Journal of Production Economics 84: pp 51-69, 2003.

23.Qiu, Y., Wang, Y. D., Wang, J. Implied discount rate and payback threshold of energy efficiency investment in the industrial sector. Applied Economics 47(21): pp 2218-2233, 2015.

24.King, P. Is the Emphasis of Capital Budgeting Theory Misplaced? Journal of Business Finance \& Accounting 2(1): pp 69-82, 1975.

25.DeCanio, S. J. and Watkins, W. E. Investments in energy efficiency: do the characteristics of firms matters? Review of Economics and Statistics 80(1): pp 95-107, 1998.

26. Markowitz, H. M. Portfolio Selection: efficient diversification of investments, John Wiley \& Sons, New York, USA, 1959.

27.Mollick, E. 'The dynamics of crowdfunding: An exploratory study', Journal of Business Venturing. The Author, 29(1), pp 1-16, 2014.

28. Baeck, P. et al. 'Commission staff working document - Report on Crowdfunding in the EU Capital Markets Union', Columbia Business Law Review, 2016(September), pp. 1-40, 2016.

29.Petkov, K. 'Equity Crowdfunding vs Some Traditional Sources of Entrepreneurial Financing: A Comparative Study', 'Research sketches', 9(1), pp 195-224, 2018.

30.Belleflamme, P., Lambert, T. and Schwienbacher, A. 'Individual crowdfunding practices', Venture Capital, 15(4), pp. 313-333, 2013.

31.Agrawal, A., Catalini, C. and Goldfarb, A. 'Crowdfunding: Geography, Social Networks, and the Timing of Investment Decisions, Journal of Economics and Management Strategy, 24 (2)', Journal of Economics and Management Strategy, 24(2), pp. 253-274, 2015.

32.Ahlers, G. et al. Signaling in Equity Crowdfunding, 2017.

33.Zvilichovsky, D., Inbar, Y. and Barzilay, O. 'Playing both sides of the market', (September), pp 1-45, 2015.

34. Yordanov, D. 'POSSIBILITIES FOR FINANCING OF SMALL AND MEDIUM ENTERPRISES THROUGH THE "GROWTH MARKET" -"BEAM" OF 
BSE-SOFIA', Entrepreneurship, VII(1), pp 64-77, 2019.

35.Choy, K. and Schlagwein, D. 'Crowdsourcing for a better world: On the relation between IT affordances and donor motivations in charitable crowdfunding', Information Technology and People, 29(1), pp. 221-247, 2016.

36.Hoegen, A., Steininger, D. M. and Veit, D. 'How do investors decide? An interdisciplinary review of decision-making in crowdfunding', Electronic Markets, 28(3), pp 339-365, 2018.

37.Grinblatt, M., and S. Titman 'Financial Markets and Corporate Strategy', New York: McGraw-Hill, 2nd edn., 2001.

38.Sharpe, W. F., G. J. Alexander and J. V. Bailey 'Investments', Englewood Cliffs, NJ: Prentice Hall International, 6th edition, 1999.

39.Elton, E. J., M. J. Gruber, S. J. Brown and W. N. Goetzmann Modern Portfolio Theory and Investment Analysis, New York: John Wiley \& Sons, 6th edition, 2003.

40.Huang, C.-F., and R. H. Litzenberger 'Foundations for Financial Economics', Englewood Cliffs NJ: Prentice Hall, 1988.

41.Merton, R. C. 'An analytic derivation of the efficient portfolio frontier', Journal of Financial and Quantitative Analysis, 7(4), pp 1851-1872, 1972.

42.Markowitz, H.M. "Portfolio Selection". The Journal of Finance. 7 (1): pp 77-91, 1952.

43.Konno, H., H. Yamazaki "Mean-Absolute Deviation Portfolio Optimization Model and Its Application to Tokyo Stock Market," Management Science, 37, 5, pp 519-531, 1991.

44.Elton, Edwin J., Martin J. Gruber, Manfred W. Padberg 'Simple Criteria for Optimal Portfolio Selection', Journal of Finance, XI, No.5, pp 1341 - 1357, 1976.

45.Elton, Edwin J., Martin J. Gruber, Stephen J. Brown, William N. Goetzmann 'Modern Portfolio Theory and Investment Analysis', 8 th edition, 2011.
BLAGOEV D., et al.

46.Saaty, T. Relative Measurement and Its Generalization in Decision Making Why Pairwise Comparisons are Central in Mathematics for the Measurement of Intangible Factors The Analytic Hierarchy/Network Process, RACSAM, Rev. R. Acad. Cien. Serie A. Mat., pp 251318, 2008.

47.Cooper, R. G., Edgett, J., Kleinschmidt, J. Portfolio Management in New Product Development: Results of an Industry Practices Study. R \& D Management, pp 361-381, 2001.

48.Cooper, R. G. Portfolio Management for Product Innovation. In Levine, H. A. (eds.) Project Portfolio Management: A Practical Guide to Selecting Projects, Managing Portfolios and Maximizing Benefit, pp 318354, 2005.

49.BCG, The Product Portfolio. Boston Consulting Group, Inc., 2007.

50.Englund, L, Graham, J. From Experience: Linking Projects to Strategy. Journal of Production and Innovation Management, pp 52-64, 1999.

51.Archer, N., Ghasemzadeh, F., An integrated framework for project portfolio selection. International Journal of Project Management, Vol. 17, pp 207-216, 1999.

52.Cooper, R. G., Edgett, J., Kleinschmidt, J. Portfolio Management in New Product Development: Lessons from the Leaders I., Research Technology Management, pp 16-28, 1997.

53.Lefley, F. "The FAP Model of Investment Appraisal" Management Accounting, pp 28-31, 2000.

54.Alexandrova, M. 'Management of portfolio of projects: Methods and Possibilities of Application', Scientific Papers of UNWE, vol. I, pp 80-104, 2007.

55.Frame, J. D. Selecting Projects that Will Lead to Success, West Chester, PA: Center for Business Practices, pp 169-181, 1994. 